$\underline{\text { Iranian Journal of Pathology | ISSN: 2345-3656 }}$

\title{
Heterotopic Pancreas as a Leading Point of Intussusception: A Case Report
}

\author{
Hiva Saffar ${ }^{1}$, Seyed Mohammad Tavangar ${ }^{2}$, Salma Sefidbakht ${ }^{3 *}$, \\ Roghayyeh Aghapour ${ }^{4}$ Fatemeh Molavi ${ }^{5}$
}

1. Associate professor, Department of Pathology, Shariati Hospital, Tehran University of Medical Sciences, Tehran, Iran

2. Professor, Department of Pathology, Shariati Hospital, Tehran University of Medical Sciences, Tehran, Iran

3. Assistant professor, Department of Pathology, Shariati Hospital, Tehran University of Medical Sciences, Tehran, Iran

4. Anatomical and clinical pathology resident, Department of Pathology, Shariati Hospital, Tehran University of Medical Sciences, Tehran, Iran

5. Internal medicine resident, Department of Internal Medicine, Shariati Hospital, Tehran University of Medical Sciences, Tehran, Iran

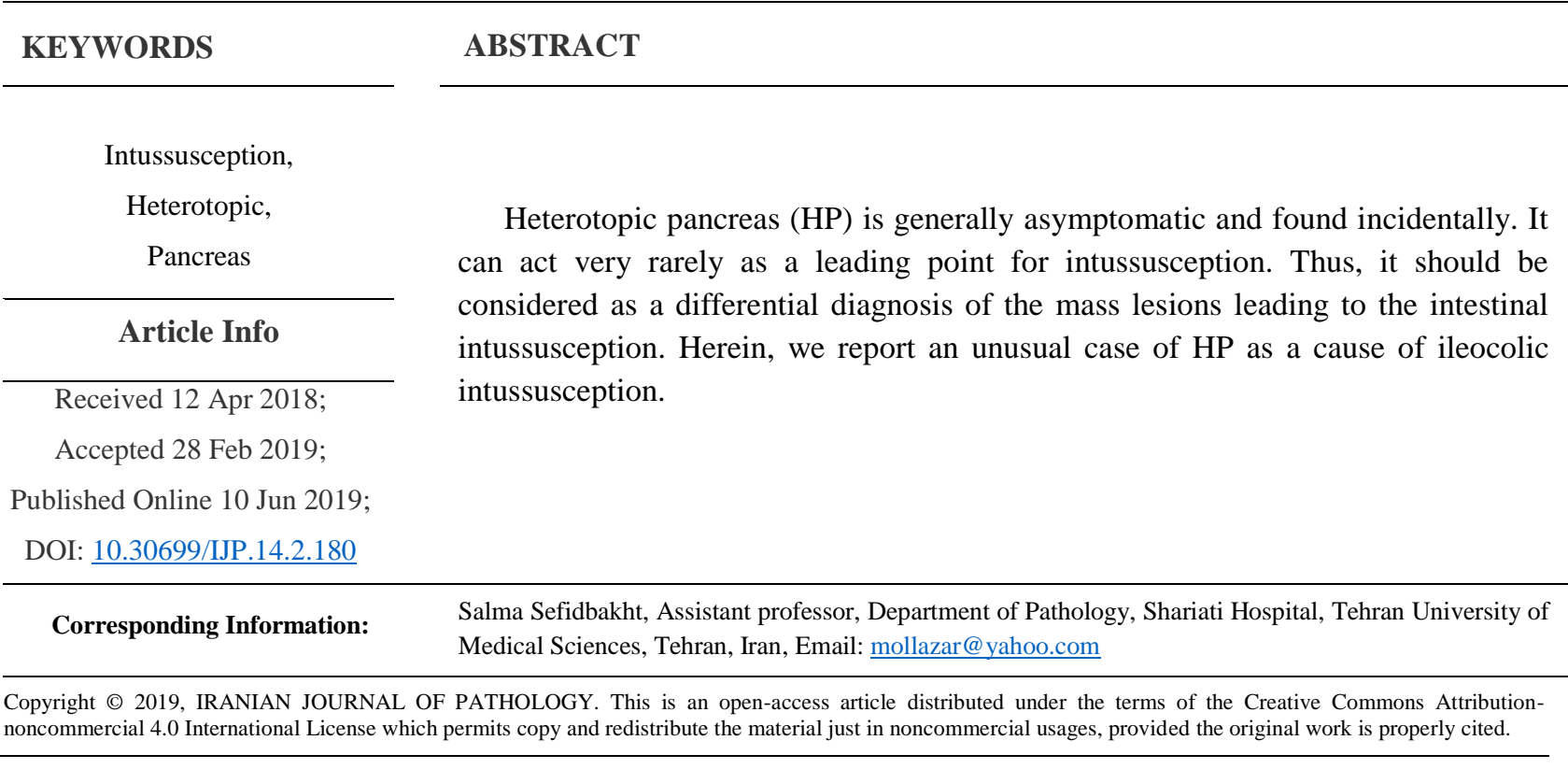

\section{Introduction}

Heterotopic pancreas (HP) also known as ectopic, aberrant accessory pancreas (1) is defined as the presence of pancreatic tissue outside its usual or habitual location lacking anatomical or vascular continuity to the main pancreas (1-5).

The incidence of ectopic pancreas varies between $0.5-3.7 \%$ which can be found at any position in the abdominal cavity (1), however, it is more common in the upper gastrointestinal (GI) tract including stomach, duodenum and jejunum (2, 3). The ileal lesions are much less common (4).

Despite rather common occurrence of HP, they are generally asymptomatic and found incidentally (1). They may become clinically symptomatic when are complicated by inflammation, bleeding, obstruction or malignant transformation $(1,5)$.

They may stand as a leading point for intussusception very rarely (1). The definite diagnosis depends on the histopathologic examination (1).

Herein, we are going to describe an unusual case of HP leading to the intestinal intussusception who was suffering from recurrent episodes of abdominal pain and melena.

\section{Case Report}

A 24-year-old male with the past medical history of peptic ulcer disease and on and off 
episodes of melena since two years ago, referred to the Emergency Department after twelve hour of severe periumbilical abdominal pain, nausea and vomiting. He stated that he had been admitted for one day with chief complains of burning epigastric abdominal pain one week ago. Physical examination revealed right upper quadrant abdominal tenderness with no rebound tenderness. Additional review of the system was unremarkable.

Distal part of ileum was irregular and thickened with areas of ulceration in small bowel series which had been performed two years earlier.

In the present admission, except for the low hemoglobin level $(12.4 \mathrm{~g} / \mathrm{dl})$, other laboratory tests results were within normal limits. Ultrasonography was performed and revealed a short segment of bowel pulled into dilated loop of intestine with a target sign appearance suggestive for intussusception. The spiral CT scan of abdomen also demonstrated ileocolic intussusception.

The patient was sent to the operation room. The diagnosis of ileocolic intussusception was confirmed. Right hemicolectomy was performed. On gross exam, the leading point was a submucosal polypoid lesion with extensive hemorrhage and ulceration measuring $2.5 \mathrm{~cm}$ in its greatest dimension. The sectioning of the mass revealed yellowish discoloration. Microscopic evaluation showed ectopic pancreatic tissue mainly located in submucosa extending deep to sub serosa with focal mucosal involvement (Figure 1). In table 1 a summary of some recently reported cases of HP leading to intestinal intussusception is demonstrated.
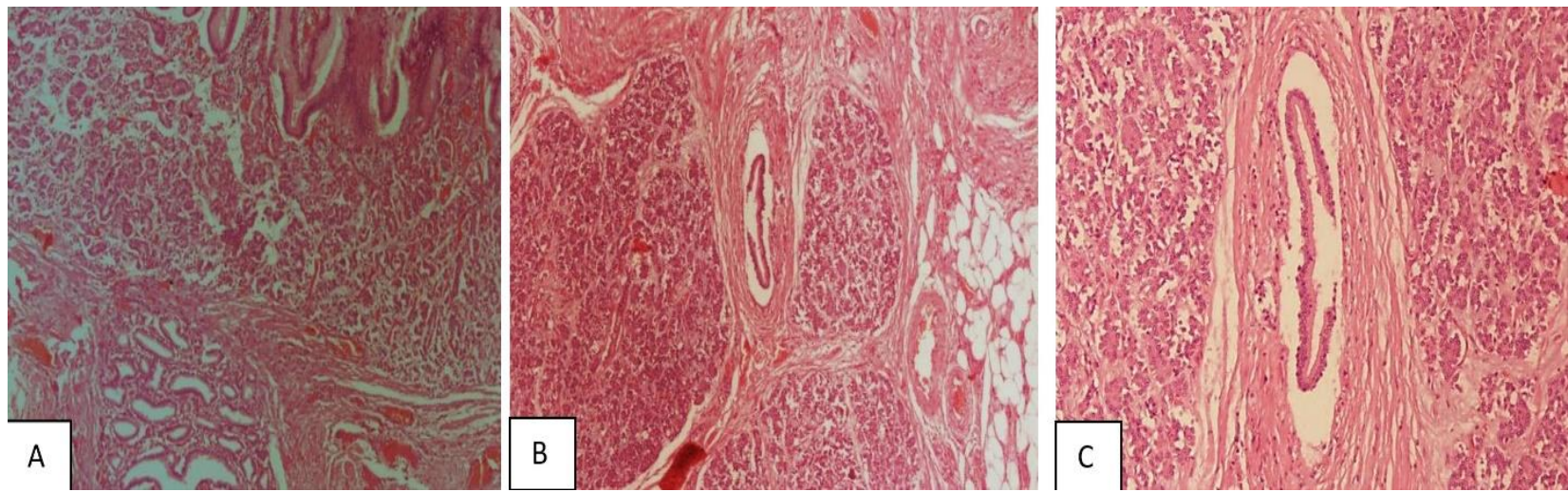

Figure 1. (A): Presence of pancreatic ducts and acini in mucosa and Submucosa of intestine. (B): Extension of the pancreatic tissue deep to sub serosa. (C): Pancreatic lobules and ducts in higher magnification.

Table 1. A summary of the cases of HP leading to intestinal intussusception

\begin{tabular}{|c|c|c|c|c|c|}
\hline No & $\operatorname{Age}(Y / O)$ & Gender & Sign/symptoms & location & Reference \\
\hline 1 & 47 & male & $\begin{array}{l}\text { On/Off episodes of melena and } \\
\text { constipation with abdominal pain }\end{array}$ & $\begin{array}{l}\text { Terminal } \\
\text { ileum }\end{array}$ & 1 \\
\hline 2 & 72 & male & $\begin{array}{l}\text { Acute onset of nausea/vomiting and } \\
\text { abdominal pain }\end{array}$ & $\begin{array}{l}\text { Ileocecal } \\
\text { junction }\end{array}$ & 2 \\
\hline 3 & 24 & male & Epigastric pain and vomiting & $\begin{array}{l}\text { Proximal } \\
\text { jejunum }\end{array}$ & 2 \\
\hline 4 & 24 & $\begin{array}{l}\text { fema } \\
\text { le }\end{array}$ & $\begin{array}{l}\text { Nausea/intermittent abdominal } \\
\text { cramping pain }\end{array}$ & jejunum & 3 \\
\hline 5 & 14 & male & Fever/severe abdominal pain & ileum & 5 \\
\hline 6 & 7 & $\begin{array}{l}\text { fema } \\
\text { le }\end{array}$ & $\begin{array}{l}\text { Intermittent cramping abdominal } \\
\text { pain }\end{array}$ & ileum & 7 \\
\hline 7 & 12 & male & $\begin{array}{l}\text { Paroxysmal colicky abdominal pain } \\
\text { with non-bilious vomiting }\end{array}$ & ileum & 8 \\
\hline 8 & 22 & $\begin{array}{l}\text { fema } \\
\text { le }\end{array}$ & $\begin{array}{l}\text { Severe abdominal pain with bile- } \\
\text { stained vomiting (pregnant) }\end{array}$ & ileum & 9 \\
\hline
\end{tabular}




\begin{tabular}{cccccc}
\hline No & Age(Y/O) & Gender & Sign/symptoms & location & Reference \\
\hline $\mathbf{9}$ & 9 & male & $\begin{array}{c}\text { Repeated episodes of colicky } \\
\text { intense periumbilical pain with bilious } \\
\text { vomiting }\end{array}$ & ileum & 10 \\
\hline $\mathbf{1 0}$ & 39 & male & Recurrent left abdominal discomfort & jejunum & 11 \\
$\mathbf{1 1}$ & 12 & male & $\begin{array}{c}\text { Severe abdominal pain with } \\
\text { intermittent vomiting }\end{array}$ & ileum & 12 \\
\hline $\mathbf{1 2}$ & $1(15$ & male & $\begin{array}{c}\text { severe colicky abdominal pain and } \\
\text { repeated bilious vomiting/bloody stool }\end{array}$ & ileum & 13 \\
\hline
\end{tabular}

\section{Discussion}

The incidence of localized pathological leading point for intussusception varies from $2 \%$ to $12 \%$ in large series (1). Isolated HP is usually asymptomatic but can act as a leading point for intussusception (1).

There are several theories explaining the occurrence of HP. One theory believes that during the embryonic rotation of the dorsal and ventral buds, fragments of the pancreas become separated and deposited at ectopic sites (1).

HP can be seen through the whole GI tract but more common cases have been reported from stomach (25-38\%), duodenum (17-36\%), and jejunum (15-21\%) (1). The involvement of other sites including ileum is very rare (1).

As mentioned earlier, HP is usually asymptomatic and identified incidentally during surgery for other conditions (1) or rarely can act as a leading point for intussusception (1).

The preoperative diagnosis is difficult. The symptomatic patients usually refer with vague abdominal pain and signs of obstruction (2). Nausea, vomiting and GI bleeding have also been reported. The present case referred for the abdominal pain and intermittent episodes of melena, which the latter was the same as the case reported by Ahmed Monier et al (1).
It is believed that symptomatic lesions are generally more than $1.5 \mathrm{~cm}$ and located adjacent to or directly involved in mucosa $(3,6)$.

Macroscopically, HP mostly appears as yellow nodule most commonly located in the submucosa with the least common serosal surface (3).

Our specimen showed submucosal lesion measuring $2.5 \mathrm{~cm}$ in the greatest dimensions with the areas of gross hemorrhage. In microscopic evaluation, the pancreatic lobules, ducts and acini were noted.

It should be mentioned that in adults, intussusception is rare and predisposing factors should be excluded (3). Therefore, to evaluate the possible causing condition, segmental resection is recommended in adults without prior attempt to reduction (3).

Finally, albeit being rare, HP should be considered as a differential diagnosis of intestinal mass lesions (7) which could act as a leading point in intestinal intussusception.

\section{Acknowledgements}

The authors thank all those who helped them writing this paper.

\section{Conflict of Interest}

The authors declare that there is no conflict of interest regarding the publication of this article.

\section{References}

1. Monier A, Awad A, Szmigielski W, Muneer M, Alrashid A, Darweesh A, Hassan H. Heterotopic pancreas: a rare cause of ileo-ileal intussusception. Polish journal of radiology. 2014;79:349- 351. https://doi.org/10.12659/PJR.890913 PMid:25302087 PMCid:PMC4189718
2. Nasser HA, Sleiman YA, Hassoun ZA, Elzaatari M, Berjawi T, Hamdan W, Allouch M. Bowel obstruction secondary to an ectopic pancreas in the small bowels: About 2 cases. International journal of surgery case reports. 2017 Jan 1;31:72-4. https://doi.org/10.1016/j.ijscr.2017.01.019 PMID:28122316 PMCid:PMC5257184

3. Kok VK, Wang TK, Lin NH, Bei JJ, Huang PH, Chen YC. Adult intussusception caused by heterotopic 
pancreas. Journal of the Formosan Medical Association. 2007 May 1;106(5):418-21.

4. Hamada Y, Yonekura Y, Tanano A, Takada K, Kato Y, Sato M, Sakaida N, Okamura A, Hioki K. Isolated heterotopic pancreas causing intussusception. European journal of pediatric surgery. 2000 Jun;10(03):197-200. https://doi.org/10.1055/s-2008-1072357 PMID: 10982052

5. Andola SK, Bhimalli SI, Mahanta AA, Harwal SR. Heterotopic Pancreas Presenting With Intussusception-A Rare Case Report. 2014;1(1):033-036

6. Armstrong CP, King PM, Dixon JM, Macleod IB. The clinical significance of heterotopic pancreas in the gastrointestinal tract. British Journal of Surgery. 1981 Jun;68(6):384-7. https://doi.org/10.1002/bjs.1800680606 PMID:7237066

7. Riccardo G, Valeria B, Giulia C, Alessia C, Luisa F, Elisabetta $\mathrm{T}$, Alessandro $\mathrm{M}$, Isabella $\mathrm{M}$, Jürgen $\mathrm{S}$. Heterotopic pancreas in Meckel's diverticulum in a 7 year-old child with intussusception and recurrent gastrointestinal bleeding: case report and literature review focusing on diagnostic controversies. African Journal of Paediatric Surgery. 2014 Oct 1;11(4). https://doi.org/10.4103/0189-6725.143172 PMID:25323189

\section{How to Cite This Article:}

Saffar H, Tavangar S, Sefidbakht S, Aghapour R, Molavi F. Heterotopic Pancreas as a Leading Point of Intussusception: A Case Report. Iranian Journal of Pathology. 2019; 14(2): 180-83. 